\title{
PENINGKATAN STATUS GIZI BALITA DENGAN GIZI BURUK MELALUI PEMBERIAN FORMULA 100
}

\author{
Murwati, Tuti Devianti \\ Kementerian Kesehatan Politeknik Kesehatan Surakarta Jurusan Kebidanan
}

\begin{abstract}
Provision Of Formula 100, The Toddler Nutritional Status. Malnutrition is still a serious problem in Indonesia which frequently occur in groups of children aged under five years. The incidence of malnutrition if not addressed will cause a negative effect on children, among other death and chronic infections. Number of children under five in the region Puskesmas Sukoharjo in late December 2013 as many as 4109 children, identified under five suffering from severe malnutrition as many as 32 children. This study was to determine the effect of formula 100 to the nutritional status of children in the region Puskesmas Sukoharjo. Ekspriment quasi design with the design of one group pre test post test design. Populations of all infants with malnutrition in Puskesmas Sukoharjo Sukoharjo number 32 toddlers. Purposiv Sampling Techniques number 26 toddlers. Statistical test bivariate analysis with paired sample t-test with a confidence level of $95 \%$ or $\alpha=5 \%$. Results of the study, the average age of a toddler 30.77 a month and $76.9 \%$ of women. Nutritional status of children before giving formula 100 wholly severe malnutrition. After administration of 100 formula, infant malnutrition status as much as 69.2\% $26.9 \%$ good nutritional status and poor nutritional status 1 child (3.8\%). The test results paired sample t-test showed no effect of formula 100 to the nutritional status of children in the region Puskesmas Sukoharjo $(p=0.001)$. In conclusion there is the influence of formula 100 to the nutritional status of children in the region Puskesmas Sukoharjo
\end{abstract}

Keywords: Delivery of formula 100, The Toddler Nutritional Status

\begin{abstract}
Abstrak: Pemberian formula 100, Status gizi balita. Kasus gizi buruk saat ini masih menjadi permasalahan serius di Indonesia dimana seringkali terjadi pada kelompok anak usia di bawah lima tahun. Kejadian gizi buruk apabila tidak diatasi akan menyebabkan dampak yang buruk bagi balita, antara lain kematian dan infeksi kronis. Jumlah balita di wilayah Puskesmas Sukoharjo pada akhir bulan Desember 2013 sebanyak 4109 balita, teridentifikasi balita yang mengalami gizi buruk sebanyak 32 balita. Penelitian ini untuk mengetahui pengaruh pemberian formula 100 terhadap status gizi balita di wilayah Puskesmas Sukoharjo. Desain quasi ekspriment dengan rancangan one group pre test post test design. Populasi semua balita dengan gizi buruk yang ada di wilayah kerja Puskesmas Sukoharjo Kabupaten Sukoharjo sejumlah 32 balita. Teknik Purposiv Sampling sejumlah 26 balita. Analisa bivariate dengan Uji statistik paired sample t-test dengan tingkat kepercayaan $95 \%$ atau $\alpha=5 \%$. Hasil penelitian, umur balita rata-rata 30,77 bulan dan $76,9 \%$ perempuan. Status gizi balita sebelum pemberian
\end{abstract}


formula 100 seluruhnya berstatus gizi buruk. Sesudah pemberian formula 100, balita status gizi kurang sebanyak $69,2 \%$ status gizi baik $26,9 \%$ dan status gizi buruk 1 anak (3.8\%). Hasil uji paired sample t-test menunjukkan ada pengaruh pemberian formula 100 terhadap status gizi balita di wilayah Puskesmas Sukoharjo $(p=0,001)$. Kesimpulannya ada pengaruh pemberian formula 100 terhadap status gizi balita di wilayah Puskesmas Sukoharjo

Kata Kunci: Pemberian Formula 100, Status Gizi Balita

\section{PENDAHULUAN}

Kasus gizi buruk saat ini masih menjadi permasalahan serius di Indonesia dimana seringkali terjadi pada kelompok anak usia di bawah lima tahun. Menurut Departemen kesehatan (2003) gizi buruk adalah suatu kondisi di mana seseorang dinyatakan kekurangan nutrisi, atau dengan ungkapan lain status nutrisinya berada di bawah standar rata-rata, nutrisi yang dimaksud bisa berupa protein, karbohidrat dan kalori. Kejadian gizi buruk apabila tidak diatasi akan menyebabkan dampak yang buruk bagi balita. Dampak yang terjadi antara lain kematian dan infeksi kronis (Soetjiningsih, 2000).

Banyak faktor yang mempengaruhi terjadinya gizi buruk, diantaranya adalah status sosial ekonomi, ketidaktahuan ibu tentang pemberian gizi yang baik untuk anak, dan Berat Badan Lahir Rendah (BBLR) (Kusriadi, 2010; Anwar.dkk, 2010). Sumber lain menyebutkan asupan makanan keluarga, faktor infeksi, dan pendidikan ibu menjadi penyebab kasus gizi buruk (Razak dkk, 2011). Beberapa penelitian menunjukkan bahwa terdapat hubungan antara faktorfaktor tersebut dengan kejadian gizi buruk. Dalam penelitian yang dilakukan di Kabupaten Lombok Timur tahun 2005 menunjukkan bahwa terdapat hubungan status ekonomi, pendidikan ibu, pengetahuan ibu dalam monitoring pertumbuhan, perhatian dari ibu,pemberian ASI, kelengkapan imunisasi, dan asupan makanan balita dengan kejadian gizi buruk (Anwar., dkk, 2011).

Pemberian makanan untuk pemulihan gizi kepada balita gizi buruk adalah upaya mengatasi masalah gizi buruk dan gizi kurang pada balita. Penanggulangan balita gizi buruk harus mendapatkan perawatan sesuai Tatalaksana Anak Gizi Buruk, salah satunya dengan pemberian formula 100.

Pemberian diet Formula 100 bagi balita gizi buruk dapat meningkatkan berat badan penderita gizi buruk. Menurut Depkes (2011) diet Formula100 diberikan pada fase transisi dan rehabilitasi,yang bertujuan mengejar ketinggalan berat badan yang dialami, mencapai berat badan normal sesuai dengan panjang badan serta agar tahap perkembangan kepandaian dan aktivitas motoriknya (duduk, merangkak, berdiri, berjalan, berlari) sesuai dengan umurnya.

Berdasarkan hasil studi pendahuluan yang peneliti lakukan di Dinas Kesehatan Kabupaten Sukoharjo pada Januari 2014 ditemukan bahwa jumlah kasus Gizi Buruk yang ada di Kabupaten Sukoharjo dari tahun ke tahun masih ada, jumlah balita yang berada di wilayah Puskesmas 
Sukoharjo pada akhir bulan Desember 2013 sebanyak 4109 balita, dan teridentifikasi balita yang mengalami gizi buruk sebanyak 32 balita.

Dinas Kesehatan Kabupaten Sukoharjo berupaya untuk lebih meningkatkan pelayanan di bidang program kesejahteraan keluarga dengan meningkatkan status gizi balita gizi buruk melalui peningkatan mutu pelayanan tatalaksana gizi buruk di Puskesmas salah satunya dengan pemberian formula 100 selama tiga bulan.

Berdasarkan penjelasan tersebut, maka perlu diketahui pengaruh pemberian formula 100 terhadap status gizi balita.

\section{METODE PENELITIAN}

Jenis penelitian pra eksperiment dengan rancangan one group pre test post test design. Penelitian ini dilaksanakan di wilayah kerja Puskesmas Sukoharjo, pada bulan Januari-Juni 2014. Tehnik purposive sampling pada Balita dengan gizi buruk di wilayah kerja Puskesmas Sukoharjo Kabupaten Sukoharjo yang memenuhi kriteria inklusi sejumlah 26 balita. Analisa bivariate dengan Uji statistik paired sample t-test dengan tingkat kepercayaan $95 \%$ atau $\alpha=5 \%$.

\section{HASIL PENELITIAN}

Karakteristik responden terdiri dari umur dan jenis kelamin. Berdasarkan hasil identifikasi, umur rata-rata responden 30,77 bulan, umur termuda 10 bulan dan tertua 57 bulan, sedangkan jenis kelamin sebesar 76,9\% adalah perempuan.

Pemberian Formula 100 dimaksud adalah makanan bergizi yang diperuntukkan bagi balita gizi buruk,yang komponennya terdiri dari campuran susu skim, gula, minyak sayur dan larutan elektrolit,yang di encerkan dengan air hangat sedikit demi sedikit sambil diaduk sampai homogen dan volume menjadi $1000 \mathrm{ml}$, dan larutan ini bisa langsung diminum atau dimasak dulu selama 4 menit. Dalam penelitian ini pemberian formula 100 dilakukan selama 2 bulan yaitu pada bulan April - Mei 2014 terhadap 26 balita gizi buruk di wilayah kerja Puskesmas Sukoharjo. Adapun penilaian status gizi balita dilakukan berdasarkan indeks antropometri WHO-NCHS BB/U.

\section{Tabel 1}

\section{Hasil Pengukuran Status Gizi Balita} sebelum dan Sesudah Pemberian Formula 100

\begin{tabular}{cccccc}
\hline \multirow{2}{*}{ No } & Status & \multicolumn{3}{c}{ Pemberian Formula 100 } \\
\cline { 3 - 6 } & gizi & \multicolumn{2}{c}{ Sebelum } & \multicolumn{2}{c}{ Sesudah } \\
\cline { 3 - 6 } & & Jumlah & $(\%)$ & Jumlah & $(\%)$ \\
\hline 1 & Baik & 0 & 0 & 7 & 26,9 \\
2 & Kurang & 0 & 0 & 18 & 69,2 \\
3 & Buruk & 26 & 100 & 1 & 3,8 \\
\hline & Jumlah & 26 & 100 & 26 & 100 \\
\hline
\end{tabular}

Tabel 2

Hasil Pengukuran Berat Badan dan z-score Sebelum dan sesudah Pemberian Formula 100

\begin{tabular}{llll}
\hline \multicolumn{5}{c}{ Berat Badan pre test } \\
\hline Mean & Min & Max & S.D. \\
8,865 & 5,7 & 11,6 & 1,851 \\
\hline \multicolumn{5}{c}{ Berat Badan post test } \\
\hline Mean & Min & Max & S.D. \\
10,062 & 6,6 & 13,6 & 1,851 \\
\hline \multicolumn{4}{c}{ z-score } \\
\hline Mean & Min & Max & S.D. \\
$-3,481$ & $-4,7$ & $-3,1$ & 0,526 \\
\hline z-score & & \\
\hline Mean & Min & Max & S.D. \\
$-2,623$ & $-3,9$ & $-1,7$ & 0,5316 \\
\hline \multicolumn{5}{c}{ Hasil pengukuran } & status gizi
\end{tabular}
balita di wilayah Puskesmas Sukoharjo bahwa terjadi peningkatan setelah diberikan formula 100 selama 2 bulan. Bahwa sebelum pemberian formula 100 seluruh balita dengan status gizi buruk dan sesudah pemberian formula 


\begin{tabular}{lccccc}
\hline & $\mathrm{n}$ & $\begin{array}{c}\text { Rerata } \\
\pm \text { s.b. }\end{array}$ & $\begin{array}{c}\text { Perbedaan } \\
\text { Rerata } \pm \text { s.d. }\end{array}$ & $\begin{array}{c}\text { IK } \\
95 \%\end{array}$ & $\mathrm{P}$ \\
\hline Z-Score & 26 & $-2,62$ & 0,85 & 0,61 & 0,000 \\
Sesudah & 26 & \pm & \pm & - & \\
Z-Score & & 0,53 & 0,58 & 1,08 & \\
Sebelum & & $-3,48$ & & & \\
& & \pm & & & \\
& & 0,53 & & \\
\hline
\end{tabular}

100 selama 2 bulan ada perubahan status gizi responden yaitu gizi kurang sebanyak 69,2\%, status gizi baik $26,9 \%$ dan status gizi buruk hanya 1 balita $(3.8 \%)$.

Berat badan responden sebelum diberikan formula 100 ratarata $8,865 \mathrm{~kg}$, berat badan terendah 5,7 $\mathrm{kg}$ dan tertinggi $11,6 \mathrm{~kg}$. Status gizi balita sebelum pemberian formula 100 semuanya $(100 \%)$ yaitu 26 balita berstatus gizi buruk dengan nilai ratarata $z$-score sebesar $-3,481$ terendah 4,7 dan tertinggi sebesar $-3,1$ serta standart deviasi sebesar 0,526.

Berat badan responden sesudah diberikan formula 100 rata-rata 10,062 $\mathrm{kg}$, berat badan terendah $6,6 \mathrm{~kg}$ dan tertinggi $13,6 \mathrm{~kg}$. Status gizi balita sesudah pemberian formula 100 dilihat dari nilai rata-rata z-score sebesar 2,623 terendah $-3,9$ dan tertinggi sebesar $-1,7$ serta standart deviasi sebesar 0,5316. Dengan melihat hasil perbedaan antara sebelum dan sesudah pemberian dapat disimpulkan terjadi perubahan berat badan dari rata - rata $8.8 \mathrm{~kg}$ menjadi $10 \mathrm{~kg}$.

Hasil pengaruh formula 100 terhadap status gizi balita di wilayah Puskesmas Sukoharjo dapat diketahui dari hasil uji beda menggunakan uji statistik paired sample t-test dari data $z$-score, diperoleh $p=0,001$ maka dapat disimpulkan ada pengaruh pemberian formula 100 terhadap status gizi balita.

Tabel 3

\section{Hasil Uji Paired Sample T-Test pengaruh pemberian formula 100 terhadap status gizi balita. PEMBAHASAN}

Berdasarkan

karakteristik responden rata-rata umur balita yang mengalami gizi buruk yaitu 30 bulan. Menurut Supariasa, et. al., (2002) menjelaskan bahwa angka kejadian gizi buruk pada usia ini sering terjadi karena pada usia ini merupakan periode penyapihan.

Anak yang disapih mengalami masa transisi pada pola makannya. Keadaan ini mengakibatkan asupan makanan berkurang. Masa ini disebut sebagai masa transisi tahun kedua (secuntrant) yaitu second year trasisional. Wong (2001) menjelaskan lebih lanjut bahwa anak usia toddler yaitu 1 sampai 3 tahun merupakan tahun pertama tahap tumbuh kembang setelah anak normal melalui masa bayi. Kebutuhan nutrisi anak usia toddler sebagian besar mengalami periode berkurangnya nafsu makan yang dikenal dengan anoreksia fisiologis. Pada masa ini toddler mengalami susah makan, memilih milih makanan dan hanya makan makanan tertentu yang mereka sukai saja.

Berdasarkan hasil penelitian bahwa mayoritas jenis kelamin balita gizi buruk baik pada kelompok intervensi maupun kelompok kontrol adalah perempuan. Menurut Jellife (1989) (dalam Supariasa, et. al., 2002) bahwa seks atau jenis kelamin merupakan faktor internal yang mempengaruhi pertumbuhan dimana laki-laki lebih panjang dan lebih berat. Hasil penelitian yang dilakukan oleh Hasbi (2007) mengenai faktor-faktor yang berhubungan dengan kekurangan energi protein pada balita di Kecamatan Batu Layar Kabupaten 
Lombok Barat jika jenis kelamin balita KEP mayoritas adalah laki-laki. Bila diamati lebih lanjut aktivitas fisik anak laki-laki lebih banyak daripada anak perempuan, dengan demikian kebutuhan energi yang diperlukan juga lebih banyak pada anak laki-laki daripada anak perempuan. Hal ini didukung dengan teori yang menyatakan bahwa kebutuhan energi pada anak laki-laki adalah $112 \mathrm{kal} / \mathrm{kg}$ BB sehari, sedangkan pada perempuan hanya 900 kalori.

Perbedaan status gizi balita sebelum dan sesudah pemberian formula 100. Hasil penelitian menunjukkan bahwa ada perbedaan status gizi balita sebelum dan sesudah pemberian formula 100 di wilayah Puskesmas Sukoharjo ( $\mathrm{p}=0,000)$. Hal ini didukung hasil pengukuran berat badan sebelum dan sesudah pemberian formula 100. Berat badan responden sebelum diberikan formula 100 ratarata $8,865 \mathrm{~kg}$, berat badan terendah 5,7 $\mathrm{kg}$ dan tertinggi $11,6 \mathrm{~kg}$ sedangkan berat badan responden sebelum diberikan formula 100 rata-rata 10,062 $\mathrm{kg}$, berat badan terendah $6,6 \mathrm{~kg}$ dan tertinggi $13,6 \mathrm{~kg}$. Status gizi balita sebelum pemberian formula 100 semuanya $(100 \%)$ yaitu 26 balita berstatus gizi buruk dengan nilai ratarata z-score sebesar -3,481 terendah 4,7 dan tertinggi sebesar $-3,1$ serta standart deviasi sebesar 0,5269. Status gizi balita sesudah pemberian formula 100 dilihat dari nilai rata-rata $\mathrm{z}$-score sebesar -2,623 terendah $-3,9$ dan tertinggi sebesar $-1,7$ serta standart deviasi sebesar 0,5316.

Penggunaan F-100 telah mengacu pada protokol WHO (Kemenkes 2011). Namun kepatuhan balita gizi buruk yang mengikuti rawat jalan di Puskesmas untuk mengkonsumsi F-100 ditemukan sehingga peningkatan status gizi setelah pemberian formula 100 masih terdapat 1 balita $(3,8 \%)$ dengan status gizi buruk. Alasannya balita bosan mengkonsumsi F-100 terus menerus, balita tidak tahan dan tidak bisa mengkonsumsi susu dan beberapa diantaranya diare (Lamid A dkk., 2009).

Pemberian diet formula 100 pada balita gizi buruk rawat jalan pada kelompok intervensi diberikan pada fase stabilisasi, rehabilitasi dan lanjutan. Tujuan tahap stabilisasi yaitu untuk mencegah terjadinya keadaan lebih buruk yakni hipoglikemia dan dehidrasi. Pada tahap stabilisasi makanan yang diberikan dalam bentuk cair, rendah kalori dan protein berupa makanan formula 100 yang diberikan secara bertahap untuk memenuhi kebutuhan anak gizi buruk. Adapun tujuan tahap rehabilitasi yaitu untuk mengejar ketinggalan berat badan yang pernah dialaminya. Makanan yang diberikan pada tahap rehabilitasi berupa makanan lumat dan makanan anak yang sesuai dengan umur. Tujuan tahap lanjutan yaitu mempertahankan peningkatan status gizi yang telah dicapai atau lebih meningkatkan status gizi yang ada dan menyesuaikan dengan pola makanan yang ada di rumah.

Kebutuhan energi pada fase ini sebesar 150-220 kkal/kg/BB/hari dengan protein sebesar 4-6 gram/kg/hari (Kemenkes,2011).

Penelitian terkait yang dilakukan oleh Arnelia, et. al. (2010) mengenai pengaruh pemulihan gizi buruk rawat secara komprehensif terhadap kenaikan berat badan, panjang badan dan satus gizi balita menunjukkan bahwa rerata peningkatan berat badan kelompok 
komprehensif setelah 3 bulan 1,39 \pm $0,66 \mathrm{~kg}$, sedangkan pada kelompok standar 0,80 $\pm 0,40(\mathrm{p}=0,001)$. Setelah 6 bulan rerata peningkatan berat badan kelompok komprehensif 2,02 $\pm 0,85$ $\mathrm{kg}$, sedangkan pada kelompok standar $1,39 \pm 0,52(\mathrm{p}=0,008)$. Kekurangan gizi pada anak balita disebabkan oleh beberapa faktor penyebab dan multi dimensi. Oleh karena itu perbaikan gizi harus dilakukan dilakukan secara menyeluruh agar dapat dicapai hasil yang optimal.

Pada kasus severe malnutrition atau gizi buruk, penanganan dianjurkan melalui rawat inap di $\mathrm{RS}$ atau therapeutic feeding center (TFC) sesuai pedoman tatalaksana yang dikeluarkan WHO dan Depkes. Kenyataan di lapangan adalah hanya sebagaian kecil kasus gizi buruk yang menjalani rawat inap dan umumnya meminta pulang sebelum pulih sesuai kriteria dalam pedoman yang dikeluarkan WHO maupun Depkes.

Penelitian ini sejalan dengan penelitian yang dilakukan oleh Sulistiyawati (2011) dimana berdasarkan kemaknaan uji Ancova terlihat bahwa hanya variabel jenis perlakuan pemberian formula 75 dan 100 (variable independen) yang signifikan mempengaruhi berat balita gizi buruk (variabel dependen) dengan $p$-value $=0,000$. Demikian juga sejalan dengan penelitian yang dilakukan oleh Astuti Lamid (2012), hasil penelitiannya menunjukkan bahwa peningkatan status gizi diamati sejak awal sampai dengan akhir penelitian. Pada awal penelitian status gizi menurut indikator $\mathrm{BB} / \mathrm{PB}, \mathrm{PB} / \mathrm{U}$ dan BB/U antara sampel kelompok F-100 dan RUTF tidak berbeda bermakna (p>0,05) (Tabel 5). Tampak ratarata $\mathrm{BB} / \mathrm{PB}$ kedua kelompok <-3,0 Z-skor dikategorikan sangat kurus. Pada akhir penelitian perubahan kategori status gizi kedua kelompok terjadi hanya menurut indikator $\mathrm{BB} / \mathrm{PB}$ dan diamati rata-rata status gizi kedua kelompok menjadi kategori kurus (BB/PB <-2,0 Z-skor). Bahkan pada dua kelompok ditemukan 8,1 sampai 10,8 persen sampel pulih menjadi gizi normal.

Berdasarkan pemaparan diatas maka dapat disimpulkan bahwa pemberian diet formula 100 berpengaruh dalam meningkatkan berat badan dan status gizi pada balita gizi buruk rawat jalan. Kerjasama yang baik antara keluarga, kader dan tenaga kesehatan selama pelaksanaan merupakan kunci keberhasilan dalam kegiatan ini. Konseling gizi juga dilaksanakan manakala selama proses kegiatan intervensi ditemukan keluarga yang menurun motivasinya sehingga dapat meminimalkan terjadinya drop out. Setyowati (2005) menyatakan bahwa peran perawat/bidan dalam menghadapi masalah gizi buruk pada balita terdiri dari membina hubungan terapeutik, sebagai advokat dari keluarga, peran dalam pencegahan panyakit/promosi kesehatan, memberikan konseling dan penyuluhan kesehatan, memberikan asuhan keperawatan, kolaborator serta pembuat keputusan secara etik.

Faktor lain yang berpengaruh dalam penanganan gizi buruk adalah stresor dari luar yaitu sosial ekonomi rendah sehingga berpengaruh terhadap ketersediaan asupan nutrisi bagi balita. Balita gizi buruk selama upaya pemulihan membutuhkan perawatan serta pendampingan secara optimal berupa dukungan secara psikologis, respon pengasuhan dari orang tua dalam hal bantuan dan perhatian segala kebutuhannya. Apabila dinalisis lebih 
jauh maka dapat disimpulkan bahwa pada kondisi balita gizi buruk membutuhkan dan melibatkan peran serta keluarga sebagai system pendukung dalam mengembalikan fungsi hidup secara biologis.

\section{KESIMPULAN DAN SARAN}

Ada pengaruh pemberian formula 100 terhadap status gizi balita di wilayah Puskesmas Sukoharjo.

\section{DAFTAR RUJUKAN}

Anwar K, Juffrie M, Julia M. 2011. Faktor Risiko Kejadian Gizi Buruk di Kabupaten Lombok Timur, Propinsi Nusa Tenggara Barat. Jurnal Gizi Klinik Indonesia [Internet].2005[cited 2011 Desember 14]:2(3):8185. Available from:http://ijcn.or.id/v2/conten t/view/33/40/

Arnelia, Anies, I., Astuti, L., Tetra, F., \& Rika, R. 2010. Pengaruh pemulihan gizi buruk rawat jalan secara komprehensif terhadap kenaikan berat badan, panjang badan, dan status gizi anak batita. Penelitian Gizi dan Makanan. 33 (2), 125-137.

Departemen Kesehatan RI. 2003. Pedoman penyuluhan gizi dan kesehatan dalam penatalaksanaan balita gizi buruk secara rawat jalan untuk Puskesmas. Jakarta:

Kemenkes RI. 2011. Pedoman pelayanan gizi buruk. Jakarta: Departemen Kesehatan RI.

Kusriadi. 2010. Analisis Faktor Risiko Yang Mempengaruhi Kejadian Kurang Gizi Pada Anak Balita Di Provinsi Nusa Tenggara
Barat (NTB) [karya tulis ilmiah].Bogor: Institut Pertanian Bogor;

Lamid A, Arnelia, Puspitasari DS dan Irawati A. 2009. Optimalisasi pertumbuhan dan perkembangan anak balita gizi buruk melalui peningk ct-m $^{+\cdots}$ pemulihan rawat ja Laporan Penelitian. Bogor: Pusat Penelitian dan Pengembangan Gizi dan Makanan.

Razak AA,Gunawan IMA, Budiningsari RD. 2009. Pola Asuh Ibu Sebagai Faktor Risiko Kejadian Kurang Energi Protein (KEP) Pada Anak Balita. Jurnal Gizi Klinik Indonesia[Internet].2009[cited 2011 Desember 14]:6(2):95103.Available from: http://www.ilib.ugm.ac.id/jurnal/download. php? dataId $=10761$

Setyowati. 2005. Peran perawat dalam pencegahan dan penanganan gizi buruk. Disampaikan pada Seminar Nasional Keperwatan Dewan Mahasiswa Program Studi Ilmu Keperawatan Poltekkes Depkes Semarang 24 September 2005

Soetjiningsih. 2000. Pedoman Diagnosis dan Terapi Ilmu Kesehatan Anak RSUP Sanglah. Denpasar: SMF Ilmu Kesehatan Anak FK Unud Denpasar

Sulistiyawati (2011). Pengaruh Pemberian Diet Formula 75 dan 100 Terhadap Berat Badan Balita Gizi Buruk Rawat Jalan di Wilayah Kerja Puskesmas Pancoran Mas 
Kota Depok. Tesis. Universitas Indonesia 